\title{
Effects of Different Liquid Smoke Treatments on Osmotic Dehydration of Apple Cubes
}

\author{
Rohit Singh \\ West Virginia University, rs0138@mix.wvu.edu
}

Follow this and additional works at: https://researchrepository.wvu.edu/etd

Part of the Food Processing Commons, Forest Sciences Commons, and the Natural Resources and Conservation Commons

\section{Recommended Citation}

Singh, Rohit, "Effects of Different Liquid Smoke Treatments on Osmotic Dehydration of Apple Cubes" (2021). Graduate Theses, Dissertations, and Problem Reports. 8282.

https://researchrepository.wvu.edu/etd/8282

This Thesis is protected by copyright and/or related rights. It has been brought to you by the The Research Repository @ WVU with permission from the rights-holder(s). You are free to use this Thesis in any way that is permitted by the copyright and related rights legislation that applies to your use. For other uses you must obtain permission from the rights-holder(s) directly, unless additional rights are indicated by a Creative Commons license in the record and/ or on the work itself. This Thesis has been accepted for inclusion in WVU Graduate Theses, Dissertations, and Problem Reports collection by an authorized administrator of The Research Repository @ WVU. For more information, please contact researchrepository@mail.wvu.edu. 


\title{
Effects of Different Liquid Smoke Treatments on Osmotic Dehydration of Apple Cubes
}

\author{
Rohit Singh \\ Thesis Submitted to \\ Davis College of Agriculture, Natural Resources and Design \\ West Virginia University
}

In partial fulfillment of the requirements for the degree of

Master of Science in

Forestry

Benjamin Dawson-Andoh, Ph.D., Chair

Kaushlendra Singh Tingi, Ph.D.

Gregory Dahle, Ph.D.

School of Forestry \& Natural Resources,

Morgantown, West Virginia

2021

Key words: Osmotic Dehydration, Liquid Smoke, Apples, Drying

Copyright 2021 Rohit Singh 


\section{Abstract \\ Effects of Different Liquid Smoke Treatments on Osmotic Dehydration of Apple Cubes}

\section{Rohit Singh}

Refined Liquid Smoke (RLS) (1\%) was incorporated during osmotic dehydration of apple cubes (10 mm each side) to observe its effect on solid gain, water loss, yield, water activity, product quality, and consumer preference. Three different treatments, POD (pure osmotic dehydration, no RLS), LSISS (RLS inside sugar solution) and PTLS (pre-treatment with RLS), were compared in this study. Osmotic dehydration was carried out using $42{ }^{\circ}$ Brix sugar solution, and the fruit to solution ratio was kept at 1:4. The osmotically dehydrated apples were evaluated for soluble solid content (SSC), water loss, and solid gained. After osmotic dehydration, apple cubes were air dried at $74{ }^{\circ} \mathrm{C}$ for 8 - 10 hours to achieve a water activity of 0.3. The final dried apple product was evaluated for moisture content, yield, water activity, color, and sensory characteristics. Statistical analysis showed that the use of RLS significantly influenced moisture content, total solid gained, water activity, and yield. Osmotic dehydrated apples produced with POD treatment had the highest moisture content (71.64\%) followed by those produced with PTLS (69.76\%) and LSISS (68.85\%) treatments. The highest SSC was observed in apples produced with PTLS (31.40 ${ }^{\circ}$ Brix) treatment suggesting a higher influx of sugar during osmotic dehydration process, and as a result highest yield was also recorded for the PTLS treatment (23.48\%).

In addition, a consumer acceptability test $(\mathrm{n}=15)$ of final dried apple snack was performed. The panelists were untrained undergraduate and graduate students (21-35 years 
old). Panelists rated all the samples for appearance, color, flavor, texture, taste and overall acceptance. Results showed that the overall acceptance for POD and PTLS treated apples was significantly higher than LSISS treated apples $(\mathrm{p}<0.02$ 


\section{Dedication}

I dedicate this thesis to my parents - Mr. Moti Singh Chauhan and Mrs. Meena Chauhan, my brother - Mohit Singh Chauhan, my sister - Khushboo Chauhan and my grandmother. 


\section{Acknowledgement}

First and foremost, I would like to thank God for providing me strength and grace on my life to successfully complete this research work during this unprecedented challenging time of the worldwide COVID 19 pandemic.

I thank USDA-NIFA for supporting this research through Agriculture and Food Research Initiative Competitive Grant Funding (Project\#17-867, Accession\# 1014996).

I would like to express my sincere gratitude to my major advisors, Dr. Benjamin Dawson and Dr. Kaushlendra Singh Tingi for all their support and advice throughout my graduate program. My appreciation also goes to, Dr. Litha Sivanandan Tingi and Dr. Melanie Paige for their continuous support, funding, and guidance in the successful completion of my graduate research work. Special thanks to Dr. Gregory Dahle for his generous assistance.

My sincere unreserved appreciation to all my family members, home and abroad for standing by me during this phase of my life and their unwavering support to ensure I achieve my dream of becoming an academician.

I would also like to thank my fiancé Diksha Tiwari for her love, support and motivation.

Finally, I would like to express my profound gratitude to my dear friends and colleagues, Vishal Verma, Vivek Saini, Kudakwashe Shumba, and Harrison Appiah for their friendship and academic help. 
Table of Contents

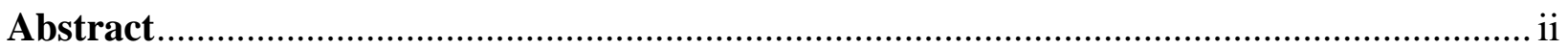

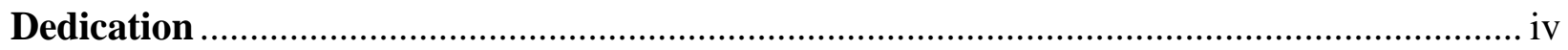

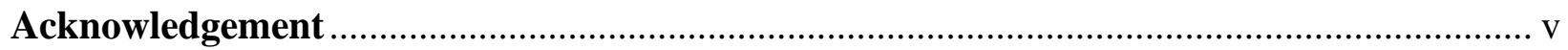

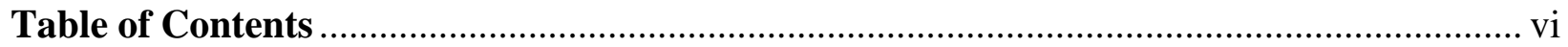

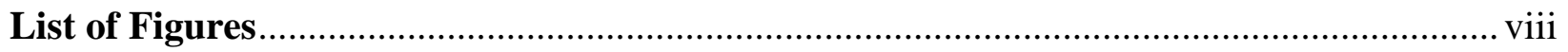

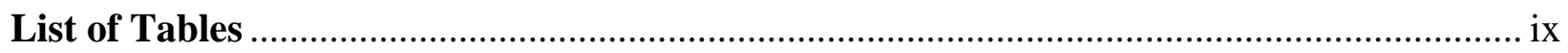

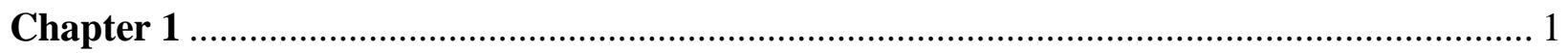

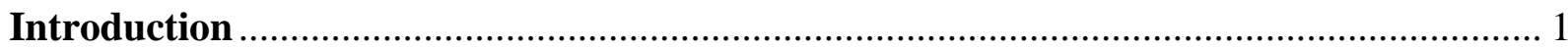

1.1 Drying and Dehydration of Apples............................................................ 2

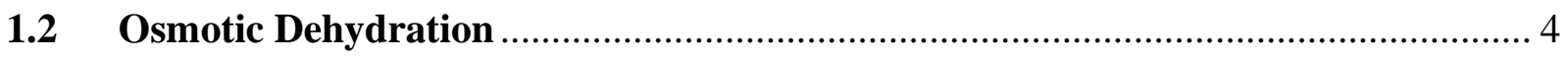

1.3 Liquid Smoke Applications on Food .............................................................. 5

1.4 Liquid Smoke Application on Osmotic Dehydration of Apples............................ 7

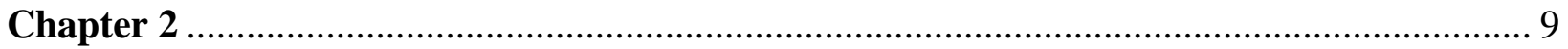

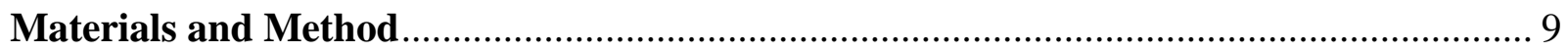

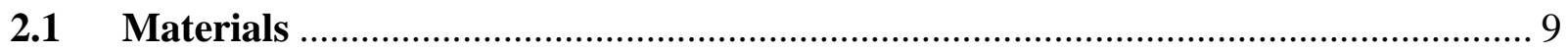

2.2 Experimental Design and Statistical Analysis .............................................. 9

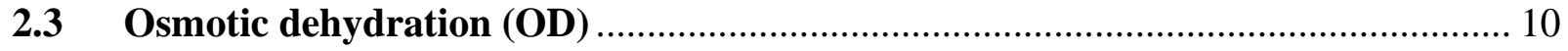

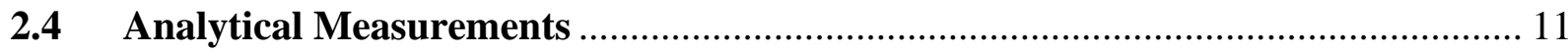


2.4.1 Soluble Solid Content (SSC, ${ }^{\circ}$ Brix) ....................................................... 11

2.4.2 Moisture Content of Apples (MC, \% ) ............................................................ 11

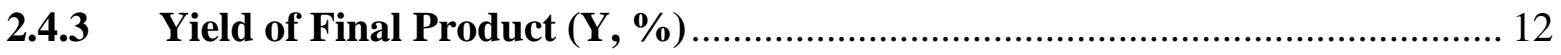

2.4.4 Solid gain (SG\%) \& water loss (WL, \% ) .................................................. 12

2.5 Consumer Acceptability Test .................................................................... 13

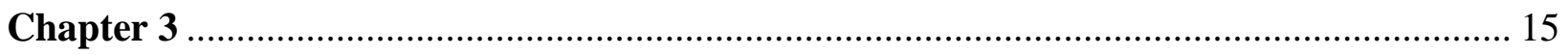

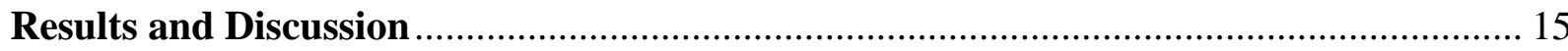

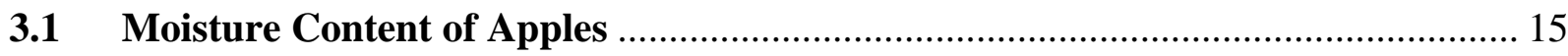

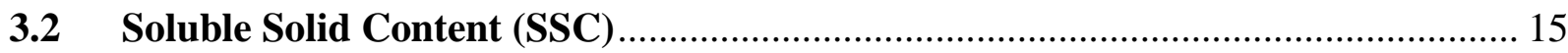

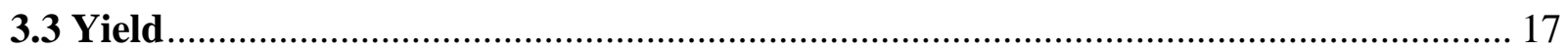

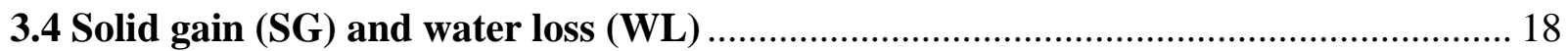

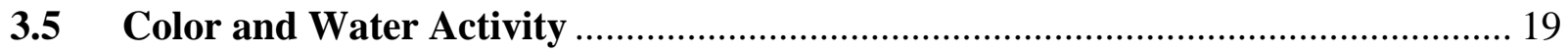

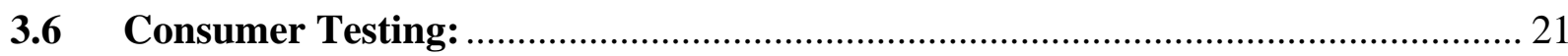

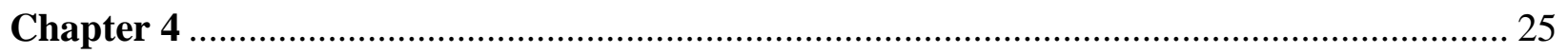

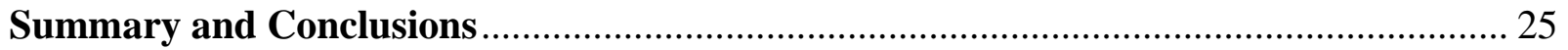

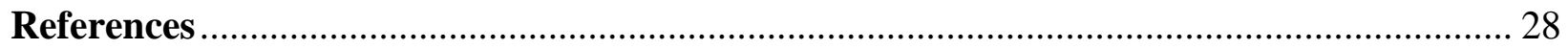




\section{List of Figures}

Figure 1. Apple Utilization in the U.S. (USDA, 2018) ....................................................... 2

Figure 2. Mass Transfer Phenomena During Osmotic Process (Torreggiani and Bertolo, 2004).. 5

Figure 3. Flow Chart for POD, LSISS and PTLS Treatments .............................................. 10

Figure 4. Schematic Diagram of OD Process Using Apple Cubes ....................................... 11

Figure 5. Brix of Apples Before and After OD .............................................................. 17

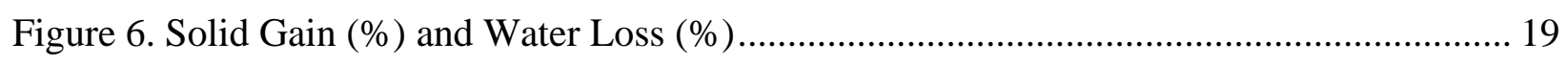

Figure 7. Color for Final Product of All Three Treatments .................................................. 19

Figure 8. L* Values Over 28 days for POD, LSISS and PTLS .......................................... 20

Figure 9. Interaction Plot of Water Activity over 28 days for POD, LSISS and PTLS ............. 21

Figure 10. Sensory characteristics (Appearance, Color, Flavor, Texture, Taste, and Overall Acceptance) rating by panelists (mean, standard error) for dried apples produce through three

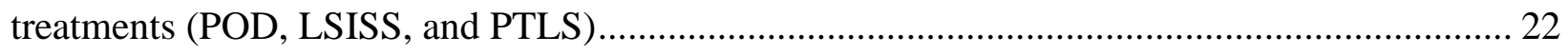

Figure 11. Interaction plot for Overall Acceptance for the Treatments Based on Age .............. 23

Figure 12. Interaction plot for Overall Acceptance for the Treatments Based on Gender. .......... 23 


\section{List of Tables}

Table 1. Moisture Content (\%) of Apples Before Osmotic Dehydration (BOD), After Osmotic

Dehydration (AOD), and After Air-Drying. ................................................................. 15

Table 2. Brix of Apples and Osmotic Solution Before Osmotic Dehydration (BOD) and After

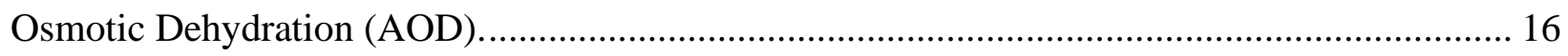

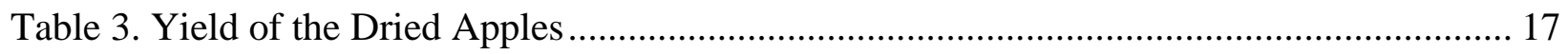

Table 4. SG and WL for POD, LSISS and PTLS treated samples ........................................ 18 


\section{Chapter 1}

\section{Introduction}

The United States is the world's second-largest producer of apples (US Apple Association, 2018). In the U.S., the apple crop production was 10.25 billion pounds in the year 2020 from 295,300 acres (USDA-NAAS, 2021). While area of apple production decreased by 15.7\% between 2007 and 2020, apple production increased by $11.3 \%$ during same time. In the United States apples are grown in 32 states. The top ten apple producing states are Washington, New York, Michigan, Pennsylvania, California, Virginia, North Carolina, Oregon, Ohio and Idaho. The Washington State alone produces more than half of the nation's apple crop (USDA, 2011). More than 100 apple varieties are grown commercially in the United States, but 15 popular varieties account for almost 90 percent of production. Fuji, Red Delicious, Gala, Granny Smith and Golden Delicious are among the most popular varieties grown in the United States (US Apple, 2020). The U.S. exports $25 \%$ of the apple crop to Mexico, India, Canada, Taiwan, Indonesia, Vietnam, United Arab Emirates, Hong Kong, Saudi Arabia, and Dominican Republic (US Apple Association, 2019).

While apples are largely consumed as fresh fruit, significant apple crop is processed into juices, dried apple, frozen apple and canned apple. According to 2018 statistics by USDA, $67 \%$ of produced apples were consumed as fresh produce; $11.9 \%$ used for making juices; $10.2 \%$ were canned; and only $3.2 \%$ were dried (Figure 1). On the other hand, $3 \%$ of total production was reported as not marketed (US Apple Association, 2018). 


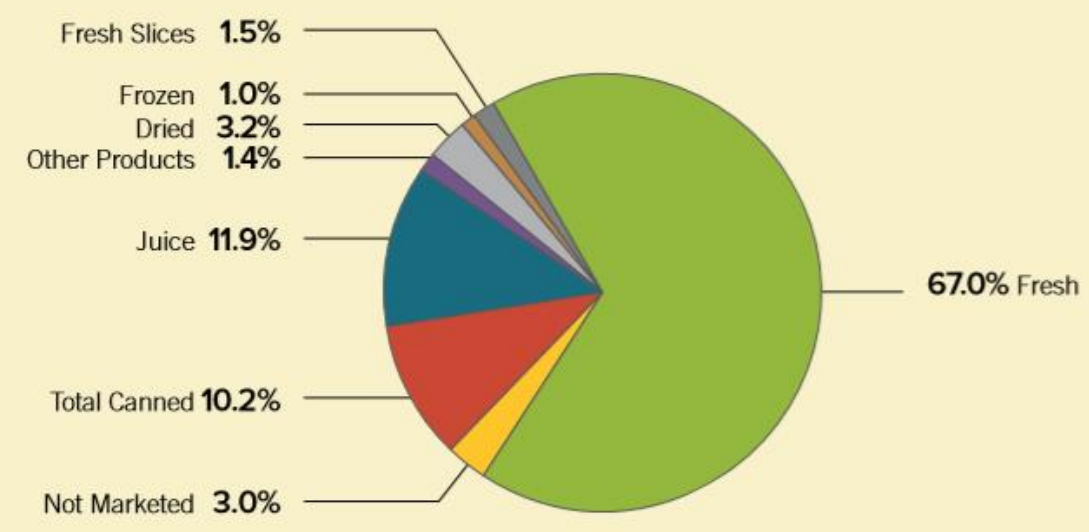

Figure 1. Apple Utilization in the U.S. (US Apple Association, 2018)

According to USDA 2019, $100 \mathrm{~g}$ of apples contain, $85.6 \mathrm{~g}$ of water, $0.26 \mathrm{~g}$ of protein, $10.4 \mathrm{~g}$ of sugars and $2.4 \mathrm{~g}$ of fiber, based on analytical data for red delicious, golden delicious, gala, granny smith and fuji verities of raw, with skin apples. Apples are also an important dietary component linked with cardiovascular disease prevention (Bondonno et al., 2017). Apples are also found to be one of the best sources for dietary polyphenols in the North American and European diet (Rupasinghe et al., 2013).

\subsection{Drying and Dehydration of Apples}

Drying of foods is commonly used to improve the food stability against microbial and enzyme activity by decreasing the water activity while minimizing physical and chemical changes during storage (Mayor \& Sereno, 2004), (Prosapio \& Norton, 2017). Apple has a significant share in food production in the world, and it is a very important raw ingredient used in many processed foods (Dikbasan, 2007). Drying and dehydration of various apples varieties using different methods has been extensively reported in the literature. Cruz et al. (2015) studied the convective drying of Golden Delicious apples at temperature ranging from 30 to $60{ }^{\circ} \mathrm{C}$. They report that drying 
decreased the acidity as well as sugar content of the apples. They also report that high temperature affected color with low $\mathrm{L}^{*}$ values and it increased mass diffusivity. Witrowa-Rajchert \& Rzaca (2009) compared drying methods (convection, microwave and infrared methods) on the internal structure of apple slices. They report that convective drying caused significant changes in the size of apple, and the apples dried using microwave and infrared methods had cells with larger crosssectional area than convectively dried apples. Also, the apple slices that were dried using microwave and infrared methods showed 11 to $12 \%$ lower shrinkage than the slices dried by the convection method. Siebert et al. (2020) studied combination drying process as an alternative to conventional drying for drying of apples. They report that using a combination of hot-air drying and microwave-vacuum drying produced better quality of dried apple pieces. Karunasena et al. (2014) performed scanning electron microscopy to study the microscopic changes to Gala apples during hot air drying. They report that cellular deformation were mainly influenced by water content throughout the drying; however, temperature also influenced the cellular deformation during the initial and intermediate stages of drying, and temperature did not deform cell structure during final stage of drying but led to case-hardening of apple. Various drying methods have been proposed in multiple literature, the most common and frequently used being hot-air drying method (Prosapio \& Norton, 2017). However, convective hot-air drying method has multiple drawbacks and can cause adverse effects on the final dried product such as excessive shrinkage, browning, little rehydration ability, low nutritive value, and poor textural properties (Lewicki \& Jakubczyk, 2004). Cost of operation for drying using a conventional air-dehydrator is also very high due to high energy requirements (Koyuncu et al., 2007).

In order to overcome these drawbacks and reduce the adverse effects of hot air drying, some pretreatments have been proposed to produce a product with intermediate moisture content. 
Among these pretreatments, osmotic dehydration has been favored because it's a low cost and simple process (Prosapio \& Norton, 2017). Osmotic dehydration (OD) helps retain better texture and flavor (Torreggiani, 1993). OD reduces Maillard browning compared to conventional drying (Torreggiani \& Bertolo, 2004).

\subsection{Osmotic Dehydration}

Osmotic dehydration (OD) facilitates removal of water from fruit without application of high heat. During osmotic dehydration, fruit is submerged in an osmotic solution (sugar or salt solution), and dehydration of fruit occurs due to osmotic pressure caused by concentration gradient. Water is transferred from the food to the solution by the virtue of the difference in osmotic pressure. During the osmotic dehydration, fruit gains salts or sugars from the osmotic solution (Figure 2). The selection of the osmotic solution and the process conditions aims at maximizing the water removal and minimizing all other transports (Berk, 2018). Osmotic dehydration, both at atmospheric pressure or preceded by the application of sub atmospheric pressure for a short time, has been proposed in the production of minimally processed fruits and vegetables, which are convenient, ready-to-eat, high-moisture but ambient stable foods (Torreggiani \& Bertolo, 2004). 


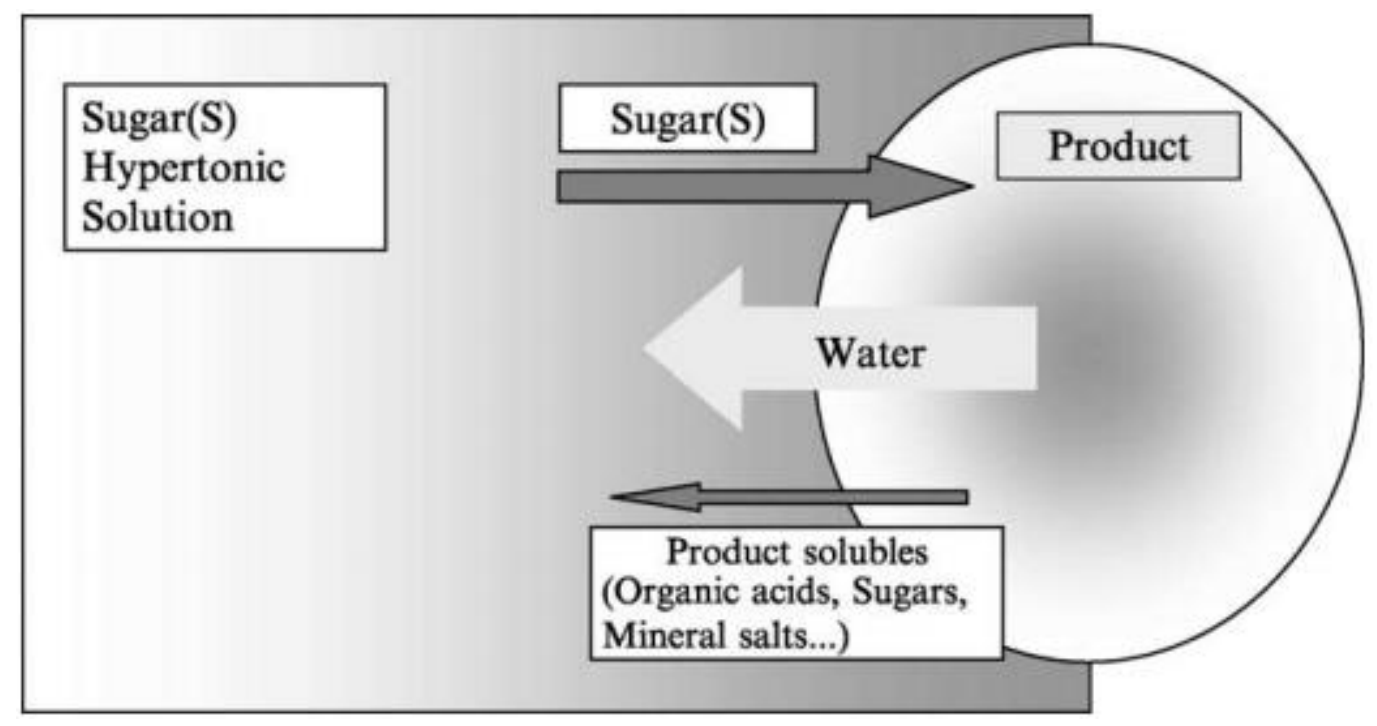

Figure 2. Mass Transfer Phenomena During Osmotic Process (Torreggiani and Bertolo, 2004).

Kaymak-Ertekin and Sultano (2000) studied the OD mechanism for apple slices at different temperatures and different concentrations of sucrose. They report that as concentration of sucrose and temperature increased the water loss also increased at considerable level. It was also noted that as the dextrose in the mixture increased the water loss as well as solid gain also increased. Kowalska (2009) observed similar effects. They report high penetration effects using higher concentration $(40 \%)$ of sucrose than $20 \%$ sucrose.

\subsection{Liquid Smoke Applications on Food}

Liquid smoke is an alternate to traditional smoking used for food preservation. Smoking techniques have been in use for centuries as a method for preserving meat and fish. Smoking provides the food with flavor and aromatic compound by impregnating the protein. Traditional smoking generates polyaromatic hydrocarbons (PAH), which are considered to be carcinogenic in nature (Hattula et al., 2001). 
Liquid smoke is produced by condensing the wood smoke produced by smoldering wood chips or sawdust under limited oxygen conditions (Montazeri et al., 2013). Raw liquid smoke contains cocktail of carbonyls, phenolic compounds, and polycyclic aromatic hydrocarbon (PAH), some of which are carcinogenic (Ayvas \& Atar, 2016). PAHs concentration of more than $300 \mathrm{ppm}$ has been proved to cause childbirth defects. Due to these toxicities, the European Union has a strict limit of $0.002 \mathrm{ppm}$ (Ayvas and Atar, 2016) for PAH. Raw liquid smoke is refined using adsorption processes to remove PAH and lignin-derived phenolic compounds. In most cases, lignin-free biomass, i.e. cellulose, carbohydrates (tapioca or corn) is used to make liquid smoke to produce phenolic-free liquid smoke. The liquid smoke after filtration and refining is called Refined Liquid Smoke (RLS). RLS is now commercially available with adjusted compositions of different compounds i.e. low phenolic compounds $(0.3$ to $0.6 \mathrm{mg} / \mathrm{ml})$ and acidity ranging from $\mathrm{pH} 2$ to 4 (Montazeri et al., 2013). Refined liquid smokes are heavily used in food systems as antimicrobials and flavoring agents (Montazeri et al., 2013 and Lingbeck et al., 2014). For example, application of RLS, inhibited Listeria monocytogenes in Salmon fish stored under vacuum at $4{ }^{\circ} \mathrm{C}$ for 35 days (Montazeri et al., 2012). Liquid smoke has long been applied for the curing of fish (Hattula et al., 2001), meat (Martinez et al., 2004), beef (Estrada-Munoz et al., 1998), and poultry products (Gomma et al., 1993). Additionally, application of RLS has shown some considerable improvement in organoleptic properties of food (Martinez et al., 2004), in terms of mechanical strength (Wang et al., 2016), texture (Martinez et al., 2004), color, and flavor (Simko et al., 2005). While there is literature on use of liquid smoke on meat products, there is very minimal research on liquid smoke use on fruits and vegetables. Rahmat \& Albaki (2021) studied the effects of coconut waste produced liquid smoke on citrus fruit pathogens. The results showed liquid smoke 
treatment $(2.5 \%)$ was able to retard mycelium of green rot (Penicillium digitatum) and blue rot (Penicillium italicum) with $100 \%$ inhibition.

\subsection{Liquid Smoke Application on Osmotic Dehydration of Apples}

Akharume et al., (2019) investigated the osmotic dehydration kinetics of water loss (WL), solid gain (SG), dry matter content (DM) and soluble solid content (SSC) of apple cubes (i) pretreated with $1 \% \mathrm{w} / \mathrm{w}$ liquid smoke plus $42{ }^{\circ}$ Brix sugar solution and (ii) pure sugar solution. They report that the use of liquid smoke treatment during OD process significantly increases the SG, DM, and SSC. For example, the liquid smoke treatment led to about $9 \%$ additional sugar gain in the apples as reflected in the dry matter content $(34.79 \%$ for liquid smoke treatment versus $31.98 \%$ for control). Additionally, the moisture content of apples was reduced from $88.50 \mathrm{~g} / 100 \mathrm{~g}$ to 47.55 $\mathrm{g} / 100 \mathrm{~g}$ for liquid smoke treated samples whereas it was $49.39 \mathrm{~g} / 100 \mathrm{~g}$ for control samples. The more SG or SSC, the better the stability, texture, and eventually the safety of the dried fruits. Therefore, one direct benefit of using liquid smoke treatment was high product yield.

In another research, Akharume et al. (2018) assessed the quality of the dried smoky apples, in comparison to pure sugar-OD treated apples and untreated apples as control, the OD treated apples were dried with hot air drying in a food dehydrator (Excalibur) set at an isothermal temperature of $74{ }^{\circ} \mathrm{C}$. Fruits were dried until reaching $0.3-0.35 \mathrm{a}_{\mathrm{w}}$ for $8 \mathrm{~h}$. Storage assay was performed in both vacuum and non-vacuum package stored at room temperature for 5 months. Microbial assay, color assay and textural properties assay were performed over time to investigate the effects of storage conditions (time and type of package) on these quality attributes. The results showed that liquid smoke treated apple snacks showed the best microbial resistance to bacteria, mold and yeast growth compared to control samples. However, none of the samples showed a growth higher than $5 \log \mathrm{cfu} / \mathrm{g}$ for all storage time. Additionally, the use of liquid smoke in the dried apple snacks 
causes the highest snacks hardness, chewiness, and gumminess during 90-120 days of storage but remain relatively the same for the $0-60$ days.

While Akharume et al. (2018 and 2019) demonstrated benefits of using liquid smoke as an additive during the osmotic dehydration process, there is a need to investigate whether liquid smoke treatment of apples prior to osmotic dehydration would lead to enhanced water loss and solid gain by acting a protein cross-linker to the apple cell wall. Therefore, objective of this research was to compare POD (pure osmotic dehydration, no liquid smoke), LSISS (RLS inside sugar solution) and PTLS (pre-treatment with RLS) for water loss (WL), solid gain (SG), dry matter content (DM), soluble solid content (SSC), and final dried product's textural and sensory characteristics. 


\section{Chapter 2}

\section{Materials and Method}

\subsection{Materials}

Golden Delicious apples were bought from a local grocery store (Kroger, USA) and stored in a refrigerator at $35^{\circ} \mathrm{F}$ (Khorshidi, 2019) prior to the experiments to avoid any spoilage. Apples were cored and then cut into cubes of approx. $10 \mathrm{~mm}$ using a slicer (Cuisinart CTG-00-MAN) and cutter. The cut apple cubes were stored inside a sealed container inside refrigerator at $35^{\circ} \mathrm{F}$ and were utilized within 10-20 minutes. A $42{ }^{\circ}$ Brix Sugar solution was prepared using distilled water and sugar bought from a local grocery store. Refined Liquid Smoke (CODE 10/POLY, Kerry Ingredients and Flavors, TN) was also purchased and stored at $4{ }^{\circ} \mathrm{C}$ before use. Complete characterization of RLS has been reported by Montazeri et al. (2013).

\subsection{Experimental Design and Statistical Analysis}

Completely randomized design was used to analyze effect of three treatments (POD, PTLS and LSISS) on response variables WL, SG, DM, and yield For the consumer acceptability test, randomized block design was used with two blocks (gender and age) to analyze five response variables (appearance, color, flavor, texture, and taste). The Experimental data were analyzed for Analysis of Variance (ANOVA) using the JMP statistical software version 15. The LSD and Tukey's tests were used to compare means. ANOVA was performed at $\alpha=0.05$. The different treatments were analyzed to evaluate statistical parameters and plots (normal probability, interaction plots). 


\subsection{Osmotic Dehydration (OD)}

To perform the osmotic dehydration experiment, fruit to solution ratio was kept 1:4 (30 g apple cubes with $120 \mathrm{~g}$ of sugar solution) according to procedure established by (Akharume et al., 2018). The OD experiment was carried out in a $150 \mathrm{ml}$ glass bottle (Model No: 1395, Corning Pyrex, Germany, Trace Code: 10063133) placed on an incubator-shaker (combi-V12, FINEPCR DAIGGER) maintained at $50{ }^{\circ} \mathrm{C}$ (Figure 4). The OD was carried out for 3 hours as established in previous work (Akharume et al., 2018). After OD, apple cubes were rinsed off gently with water to remove the excessive sugar solution coating on the surface of apples followed by hot air drying in a food dehydrator (Model: 3900T, Excalibur Products, CA. USA) for 10 hours at a temperature of $74^{\circ} \mathrm{C}$. A flow diagram for all the three treatments are present as Figure 3. To get PTLS treatment additional step A is performed after step 2 followed by step 4 and to get LSISS treatment step B is added as shown in the flow chart.

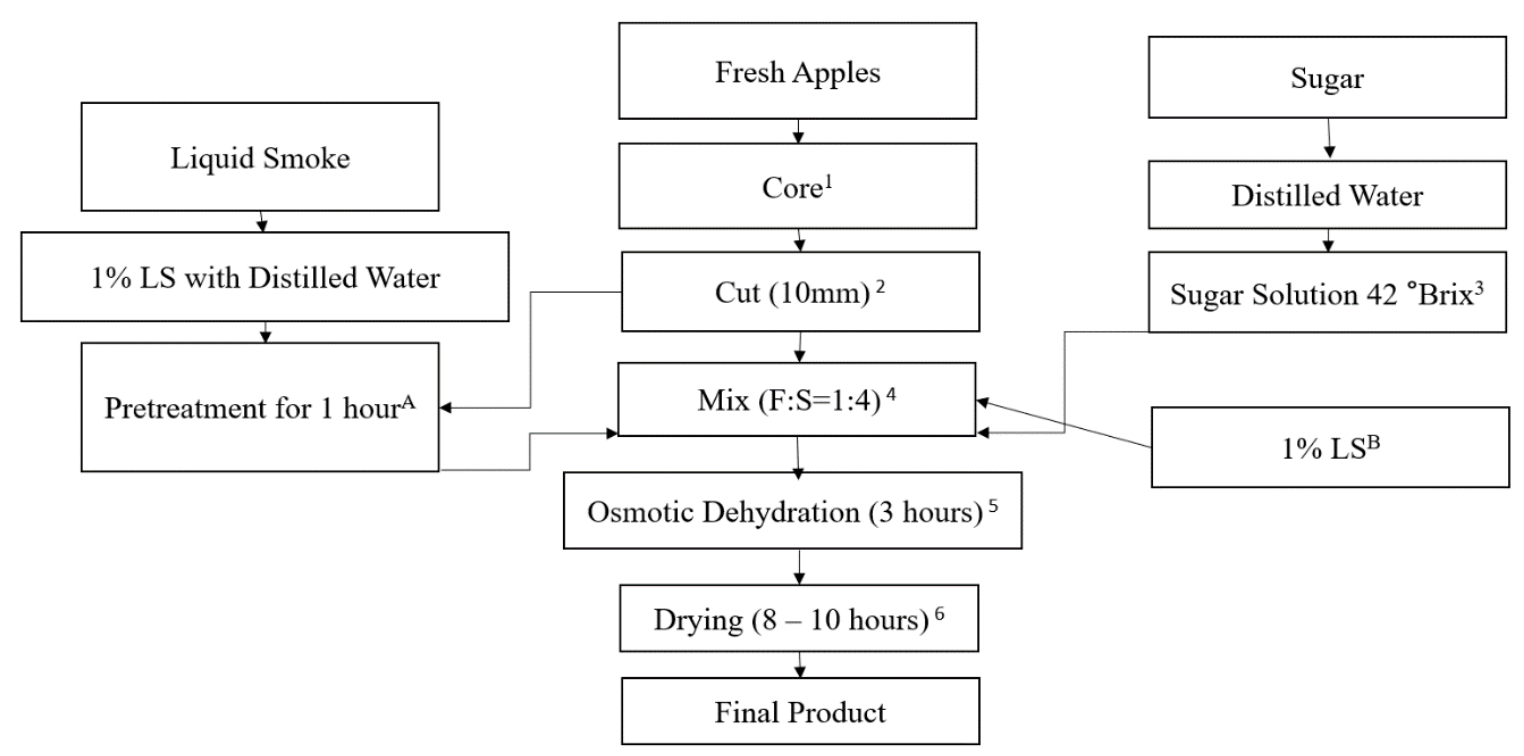

Figure 3. Flow Chart for POD, LSISS and PTLS Treatments 
For pure OD, apple cubes were dipped inside sugar solution of $42^{\circ}$ Brix. For LSISS, $1 \%$ RLS was added to the sugar solution. For PTLS, apple cubes were first pretreated with 1\% RLS solution in distilled water for 1 hour. The RLS pretreated apple cubes were gently wiped using a paper towel. After that, the RLS treated apple cubes were placed inside sugar solution of $42{ }^{\circ} \mathrm{Brix}$ and OD procedure was carried out as mentioned previously.

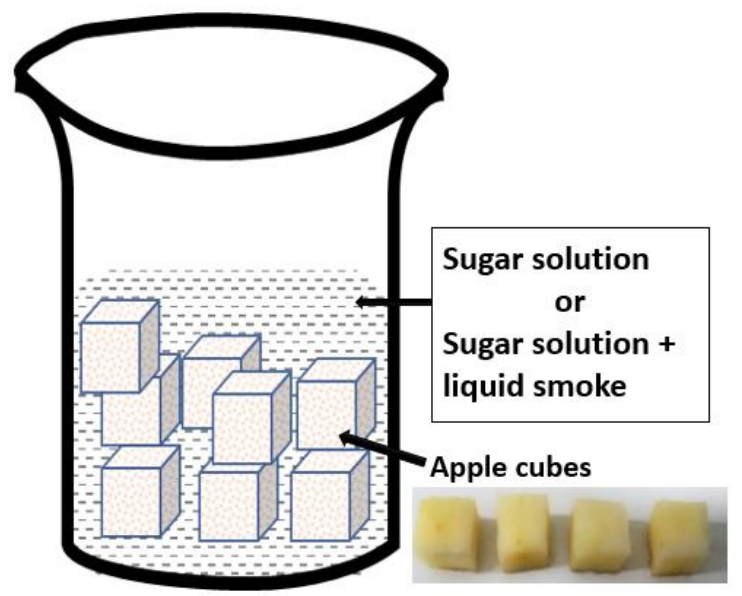

Figure 4. Schematic Diagram of OD Process Using Apple Cubes

\subsection{Analytical Measurements}

\subsubsection{Soluble Solid Content (SSC, ${ }^{\circ}$ Brix)}

SSC of the apple cubes and osmotic solution were measured before and after the OD using a digital refractometer (Model: AR200, Reichert, NY USA) according to the AOAC 932.12 standard (AOAC, 1990). To determine the brix of apples, 2-4 cubes were squeezed to extract juice, and the juice was placed on the prism of refractometer to get the measurements.

\subsubsection{Moisture Content of Apples (MC, \%)}

Moisture content of apples was measured at three different stages throughout the experiment. For fresh apple cubes (apples before osmotic dehydration, BOD); for apple cubes after osmotic 
dehydration AOD; and for apple cubes after hot air drying (final product). Moisture content and dry matter content (DM) measurements were performed by oven-drying the samples to constant weight for $24 \mathrm{~h}$ at the temperature of $103 \pm 2{ }^{\circ} \mathrm{C}$.

\subsubsection{Yield of Final Product (Y, \%)}

Percentage yield for the final product was calculated using the Equation 1.

$$
\mathrm{Y} \%=\frac{\text { Weight of air-dried product }}{\text { Weight of apples before OD }} \times 100
$$

\subsubsection{Solid Gain (SG\%) \& Water Loss (WL, \%)}

To calculate percentage water loss WL, weight of fruit (g) (cut apple cube) was measured before and after osmotic dehydration. Moisture content of fruit was also noted for before and after osmotic dehydration. With the help of moisture content, the exact water amount inside the fruit, before and after osmotic dehydration was calculated. These values of water amount were then used to get the total percentage water loss (WL) (expressed as g of water loss per $100 \mathrm{~g}$ of fruit). In similar fashion, percentage solid gained (SG) (expressed as g of solid gained per $100 \mathrm{~g}$ of fruit) was calculated with help of weight of dry matter ( $\mathrm{g}$ ) before and after osmotic dehydration. Equations used for SG and WL are as follows:

$$
\begin{aligned}
& \mathrm{WL}(\%)=\frac{\mathrm{W}_{\mathrm{BOD}}-\mathrm{W}_{\mathrm{AOD}}}{\mathrm{W}_{\mathrm{F}}} \times 100 \\
& \mathrm{SG}(\%)=\frac{\mathrm{DM}_{\mathrm{AOD}}-\mathrm{DM}_{\mathrm{BOD}}}{\mathrm{W}_{\mathrm{F}}} \times 100
\end{aligned}
$$

Where:

$\mathrm{W}_{\mathrm{BOD}}=$ water before $\mathrm{OD}(\mathrm{g})$ 


$$
\begin{aligned}
& \mathrm{W}_{\mathrm{AOD}}=\text { water after OD }(\mathrm{g}) \\
& \mathrm{DM}_{\mathrm{BOD}}=\text { dry matter before OD }(\mathrm{g}) \\
& \mathrm{DM}_{\mathrm{AOD}}=\text { dry matter after OD }(\mathrm{g}) \\
& \mathrm{W}_{\mathrm{F}}=\text { weight of fruit taken }(\mathrm{g})
\end{aligned}
$$

\subsection{Consumer Acceptability Test}

To test the marketability of the final dried apple snack product, a consumer sensory evaluation was conducted according to the standard protocol (Poste el al., 1991). Approval for consumer testing was obtained from the West Virginia University Institutional Review Board (IRB) under exempt protocol (protocol\#: 2104276063). The sensory evaluations were carried out by 15 untrained panelists (18 to 34 years old) comprising of $25 \%$ of female panelists.

For a sensory evaluation test, three coded samples labeled A, B and C were provided to a panel of 15 consumers. The test was conducted individually to stay in accordance with the West Virginia University (WVU) COVID-19 protocols. The consumer test took place in Percival Hall, Evansdale Campus, WVU, under well-lit, soundproof conditions to reduce suggestion effect and distraction error (Sharif et al., 2017). The lightning and other conditions that might affect the visual characteristics (appearance, color) were kept the same for all panelists and for all the samples. The Hedonic response of preceding sample can influence the attribute of the next sample as a result samples placed at first position generally gets higher score on a Hedonic scale (Sharif et al., 2017), also known as "order effect". In order to overcome this order effect, randomization of the samples was adopted e.g. for first 5 panelists sample A could be POD and for next 5 panelists sample A could be PTLS or LSISS. Panelist rated all the samples on a scale from 1 to 9 (Hedonic scale) with 1 being 'dislike extremelty' and 9 being 'like extremely'. Water was provided after each sample 
to rinse taste from the previous sample. Panelists rated each sample for appearance, color, flavor, texture, and taste. All the samples were served at room temperature $\left(72^{\circ} \mathrm{F}\right)$. 


\section{Chapter 3}

\section{Results and Discussion}

\subsection{Moisture Content of Apples}

Moisture content of the apple cubes Before Osmotic Dehydration (BOD), After Osmotic Dehydration (AOD), and after air drying are present in Table 1. The fresh apple had about $85.5 \%$ moisture. Similar moisture content for fresh apples reported by Ramaswami \& Tung (1981) at (85.8\%) and by USDA (2019) (85.6\%). The moisture content of the apple cubes decreased after the OD from $85.5 \%$ (MC of fresh apples) to $71.64,68.85$ and $69.76 \%$ for POD, LSISS and PTLS, respectively. The highest moisture loss was noted in LSISS followed by PTLS. However, the moisture loss after OD was not significantly more for PTLS than POD but for LSISS it was significant. Final moisture content of the apple cubes after tray drying was recorded to be 6.01, 5.65 and $5.96 \%$ again for POD, LSISS and PTLS, respectively.

Table 1. Moisture Content (\%) of Apples Before Osmotic Dehydration (BOD), After Osmotic Dehydration (AOD), and After Air-Drying.

\begin{tabular}{cccc}
\hline Treatment & BOD & AOD & After tray drying \\
\hline POD & $85.5 \pm 1.14$ & $71.64 \pm 0.42^{\mathrm{a}}$ & $6.01 \pm 2.15$ \\
LSISS & $85.5 \pm 1.14$ & $68.85 \pm 1.08^{\mathrm{b}}$ & $5.65 \pm 2.02$ \\
PTLS & $85.5 \pm 1.14$ & $69.76 \pm 1.43^{\mathrm{b}, \mathrm{a}}$ & $5.96 \pm 1.95$ \\
\hline
\end{tabular}

\subsection{Soluble Solid Content (SSC)}

Soluble solid content of the fresh apples was $12.6^{\circ}$ Brix, very close to that reported by (Romano at el., 2011) (13.1 $\pm 0.9^{\circ}$ Brix). After the OD, SSC of apples increased to as high as $31.40^{\circ}$ Brix for treatment that had liquid smoke (Table 2, Figure 5). The PTLS showed the highest increase in 
SSC (31.40 ${ }^{\circ}$ Brix), an increase of about $150 \%$. Whereas, for LSISS and POD, the SSC values were 28.43 and 28.17, respectively. These values differed slightly from the previous work (31.02 and $33.80{ }^{\circ}$ Brix) on liquid smoke infusion on OD of apples by Akharume et al., (2018). The difference could be attributed to shorter OD duration of 180 min used in this study than 240 min used by Akharume et al., (2018). The increased in OD duration results in relatively large influx of sugar (Eren \& Kayamak-Ertekin, 2007).

Table 2. Brix of Apples and Osmotic Solution Before Osmotic Dehydration (BOD) and After Osmotic Dehydration (AOD).

\begin{tabular}{ccc}
\hline & SSC of Apples $\left({ }^{\circ}\right.$ Brix $)$ & \\
\hline Treatment & BOD & AOD \\
\hline POD & $12.6 \pm 0.8$ & $28.17 \pm 0.32^{\mathrm{a}}$ \\
LSISS & $12.6 \pm 0.8$ & $28.43 \pm 3.43^{\mathrm{a}, \mathrm{b}}$ \\
PTLS & $12.6 \pm 0.8$ & $31.40 \pm 1.55^{\mathrm{b}}$ \\
\hline POD & SSC of Solution $\left({ }^{\circ}\right.$ Brix $)$ & $37.63 \pm 0.15$ \\
LSISS & $41.93 \pm 0.25$ & $36.93 \pm 0.11$ \\
PTLS & $41.93 \pm 0.25$ & $36.73 \pm 0.58$
\end{tabular}

SSC of solution reduced from $41.93{ }^{\circ}$ Brix to about as low as $31.40{ }^{\circ}$ Brix (Table 2). The PTLS treatment resulted in the highest reduction in the SSC of the solution followed by LSISS, which suggests higher influx of sugar inside the apples for PTLS than for LSISS and POD. 


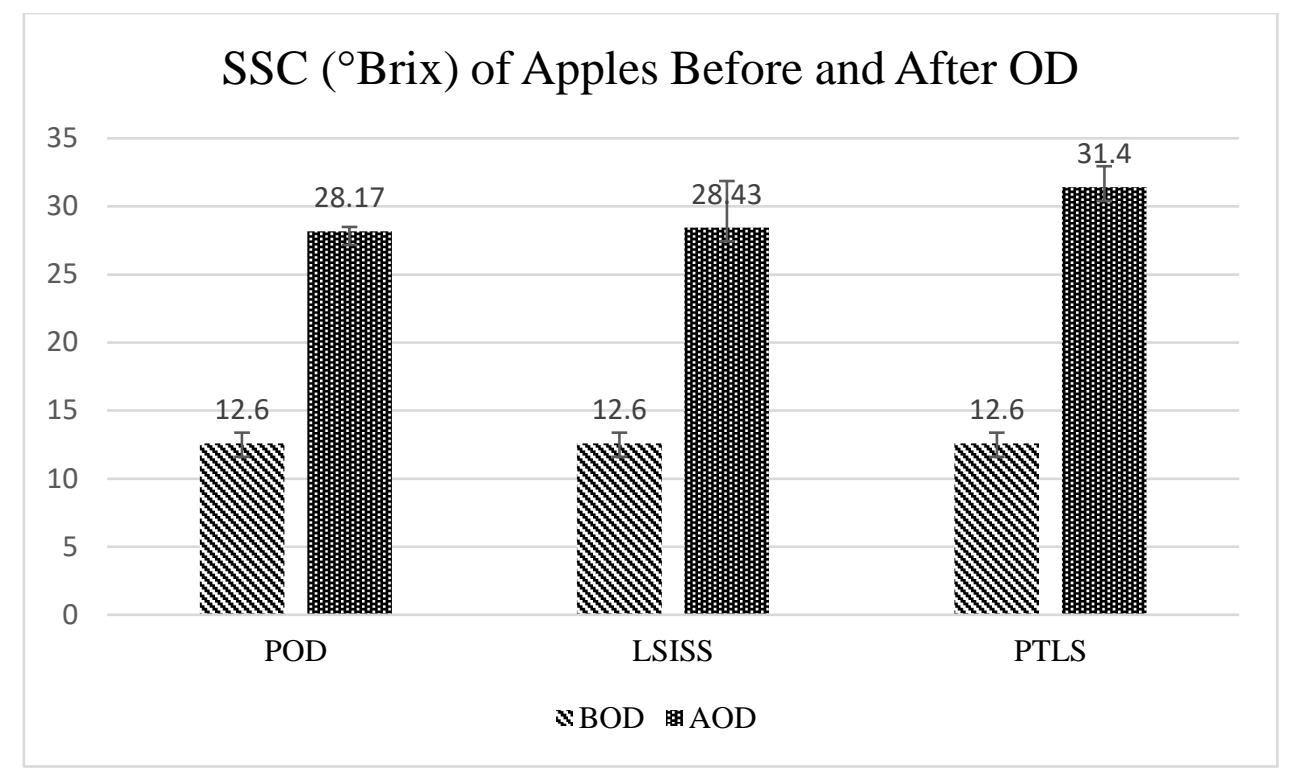

Figure 5. Brix of Apples Before and After OD

\subsection{Yield}

Tray drying of osmotically dehydrated apples was performed to reach water activity of less than 0.3. The air-dried samples had water activity of $0.19,0.266,0.259$ for POD, PTLS, and LSISS treated apples, respectively. These water activity measurements are taken immediately after air drying. in general, with increase in temperature water activity decreases. In literature, apples dried at $74{ }^{\circ} \mathrm{C}$ for 8 hours reached water activity of 0.3 (Scott \& Bernard, 1983).

Table 3. Yield of the Dried Apples

\begin{tabular}{cc}
\hline Treatment & Yield \% \\
\hline POD & $19.82 \pm 0.73^{\mathrm{a}}$ \\
LSISS & $22.53 \pm 1.32^{\mathrm{b}}$ \\
PTLS & $23.47 \pm 0.49^{\mathrm{b}}$ \\
\hline
\end{tabular}


The PTLS treatment resulted in the highest yield of $23.48 \%$, which was the highest among all three treatments followed by LSISS treatment $(22.53 \%)$. The product yield was observed to be $19.82 \%$ for POD treatment. The use of liquid smoke during OD increases product yield by $18.5 \%$, which is very good for improving output of commercial processes. Yields for PTLS and LSISS was not significantly different $(\mathrm{p}>0.05)$, however, yield for PTLS and LSISS was significantly more than POD treatment $(\mathrm{p}<0.05)$.

\subsection{Solid gain (SG) and water loss (WL)}

SG and WL for all three treatments is reported in the Table 4 and Figure 6. Highest solid gain was found in PTLS (8.38 \%) followed by LSISS (7.37 \%). Anitha (2007) recorded similar results for SG $(6.25$ to $13.97 \%$ ) for osmotically dehydrated guava. Water loss was the least for PTLS (34.28 $\%$ ) and the highest for LSISS (38.77\%). Akharume et al. (2018) reported higher WL for liquid smoke infused apples due to OD performed for 240 minutes. Akharume et al. (2018) also reported similar WL for POD and RLS infused apples. It is to be noted that both SG and WL were calculated after osmotic dehydration for all treatments.

Table 4. SG and WL for POD, LSISS and PTLS treated samples

\begin{tabular}{ccc}
\hline Treatment & SG \% & WL \% \\
\hline POD & $5.59 \pm 0.83^{\mathrm{a}}$ & $36.44 \pm 1.60$ \\
LSISS & $7.37 \pm 0.98^{\mathrm{a}, \mathrm{b}}$ & $38.77 \pm 2.12$ \\
PTLS & $8.38 \pm 0.76^{\mathrm{b}}$ & $34.28 \pm 2.32$ \\
\hline
\end{tabular}




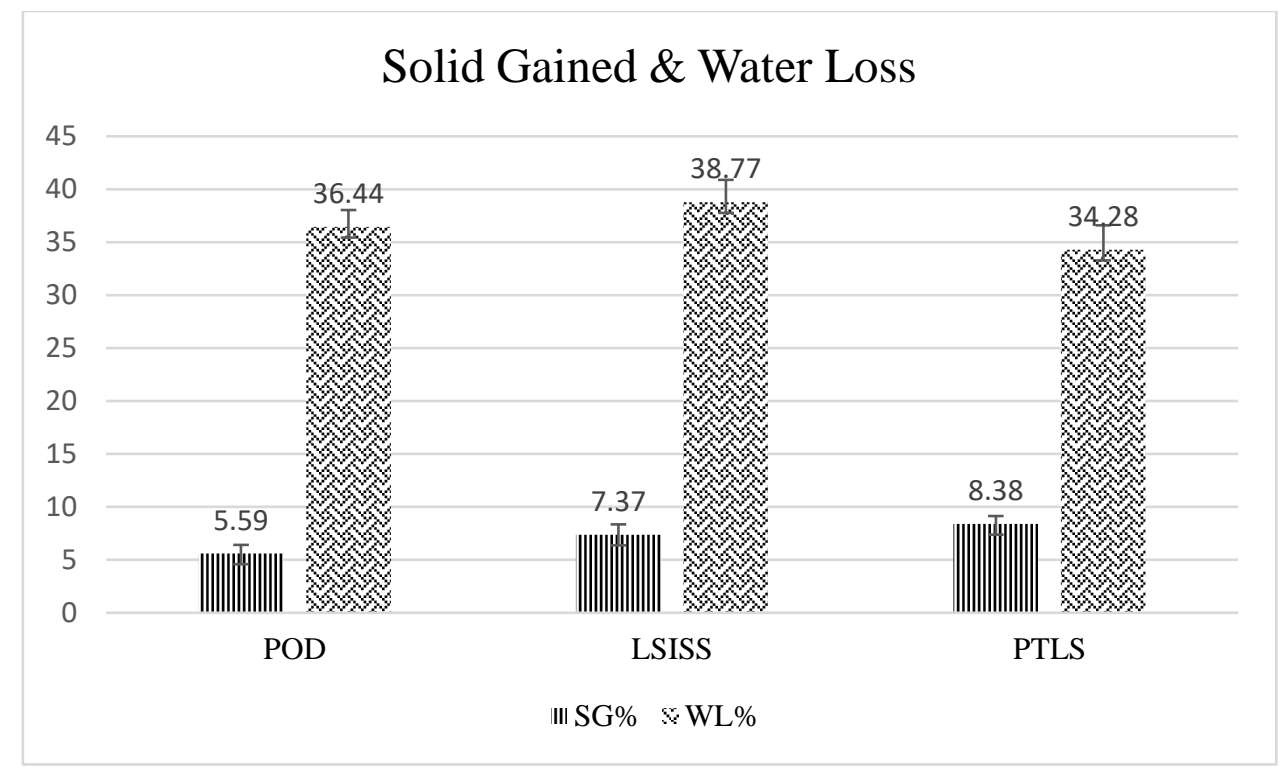

Figure 6. Solid Gain (\%) and Water Loss (\%)

\subsection{Color and Water Activity}

Color stayed consistent throughout the storage period for all the treatments (Figure 7). Color difference between the three treatments can be noticed visually, with LSISS being the darkest and POD being the lightest in color.

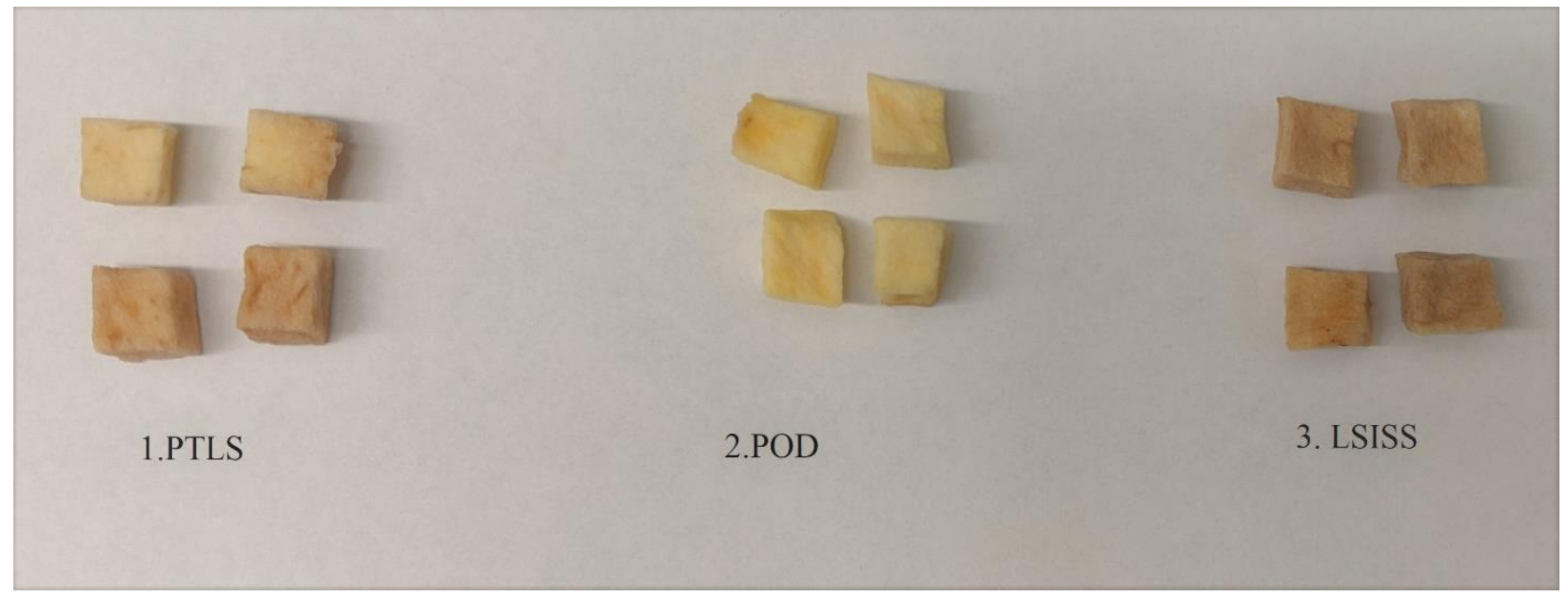

Figure 7. Color for Final Product of All Three Treatments 
The $\mathrm{L}^{*}$ values were the highest for POD treatment since it did not have any liquid smoke in it and among the liquid smoke treated apples the $\mathrm{L}^{*}$ values were higher for PTLS than LSISS treatment.

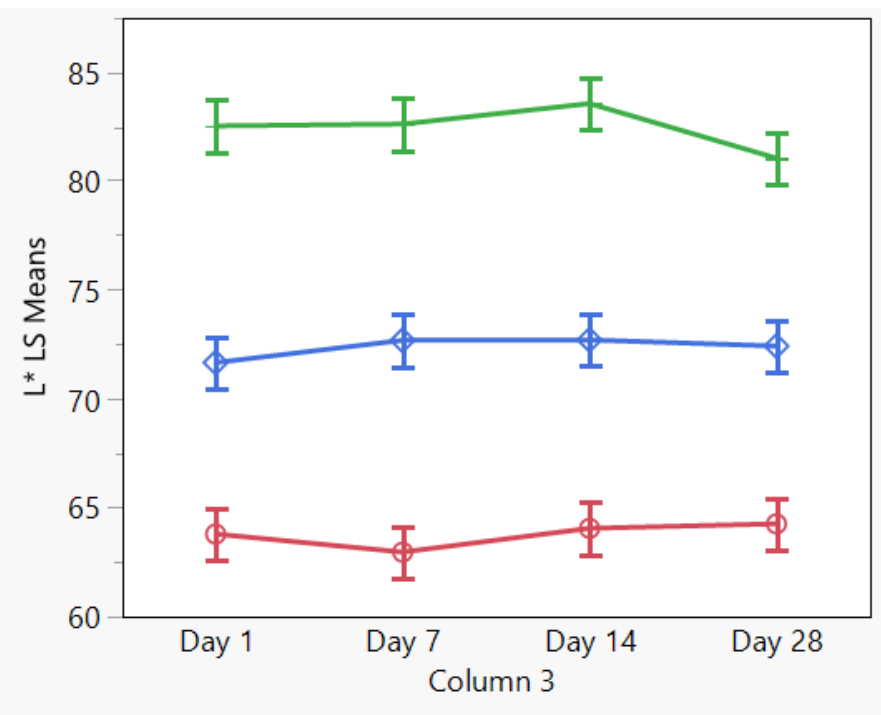

\begin{tabular}{|c|c|c|}
\hline \multicolumn{3}{|l|}{$\begin{array}{l}\text { Treatment } \\
\circ \text { - LSISS } \\
+ \text { - POD } \\
\diamond-\text { PTLS }\end{array}$} \\
\hline Level & & $\begin{array}{r}\text { Least } \\
\text { Sq Mean }\end{array}$ \\
\hline POD,Day 14 & A & 83.560000 \\
\hline POD,Day 7 & A & 82.620000 \\
\hline POD,Day 1 & A & 82.532000 \\
\hline POD,Day 28 & A & 81.050000 \\
\hline PTLS,Day 14 & B & 72.703000 \\
\hline PTLS,Day 7 & B & 72.682000 \\
\hline PTLS,Day 28 & B & 72.418000 \\
\hline PTLS,Day 1 & B & 71.659000 \\
\hline LSISS, Day 28 & C & 64.253000 \\
\hline LSISS, Day 14 & C & 64.047000 \\
\hline LSISS,Day 1 & C & 63.785000 \\
\hline LSISS,Day 7 & C & 62.952000 \\
\hline
\end{tabular}

Figure 8. L* Values Over 28 days for POD, LSISS and PTLS

The water activity for POD decreased from day one to last day of storage; however, the decrease was not significant. Maltini et al. (2003) studied the relation between mallard browning and water activity. Maltini et al. (2003) observed a relation between $\mathrm{L}^{*}$ value and water activity of dried apples. They report that the maximum browning (lower $\mathrm{L}^{*}$ values) was observed in most cases at higher water activities $(0.3-0.7)$. This explains the results of color for POD on the $28^{\text {th }}$ day when the $\mathrm{L}^{*}$ values were the lowest due to high water activity. However, this reasoning cannot be applied for PTLS and LSISS treatment because the browning was caused by liquid smoke infusion and not by mallard reaction. 

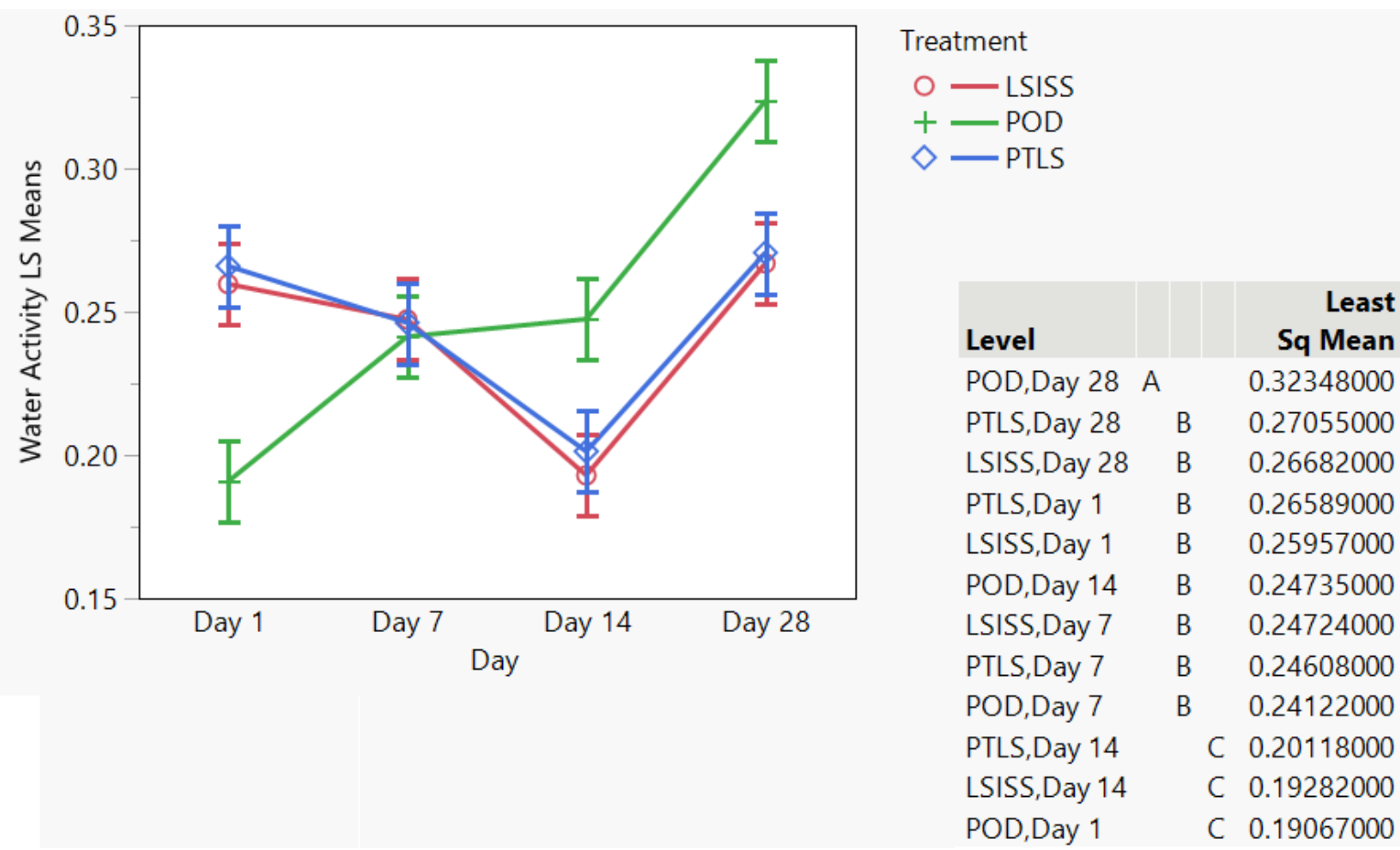

Figure 9. Interaction Plot of Water Activity over 28 days for POD, LSISS and PTLS

Water activity was not significantly different for all three treatments for the most part. However, RLS infused apples did show lower water activity over longer period.

\subsection{Consumer Acceptability}

Statistical analysis showed (Figure 10) that, appearance as well as color of POD treated apples was preferred over apples produced from other two treatments ( $\mathrm{p}$-values<0.002). Among RLS treated apples, appearance of PTLS treated apples was preferred over LSISS treated apples ( $\mathrm{p}$-value= 0.048), and color of PTLS treated apples was preferred over LSISS treated apples ( $\mathrm{p}$-value= 0.018). Texture of POD apples was not preferred over apples produced from other two treatments (p-values>0.002). Texture of PTLS treated apples was preferred over LSISS treated apples ( $p$ value $=0.028)$. Overall acceptance, flavor, and taste of POD and PTLS apples was preferred over 
apples produced from LSISS treatment $(\mathrm{p}$-values $<0.02)$. Between RLS treated apples, PTLS treatment was preferred over LSISS treated apples ( $\mathrm{p}$-value $=0.0047)$.

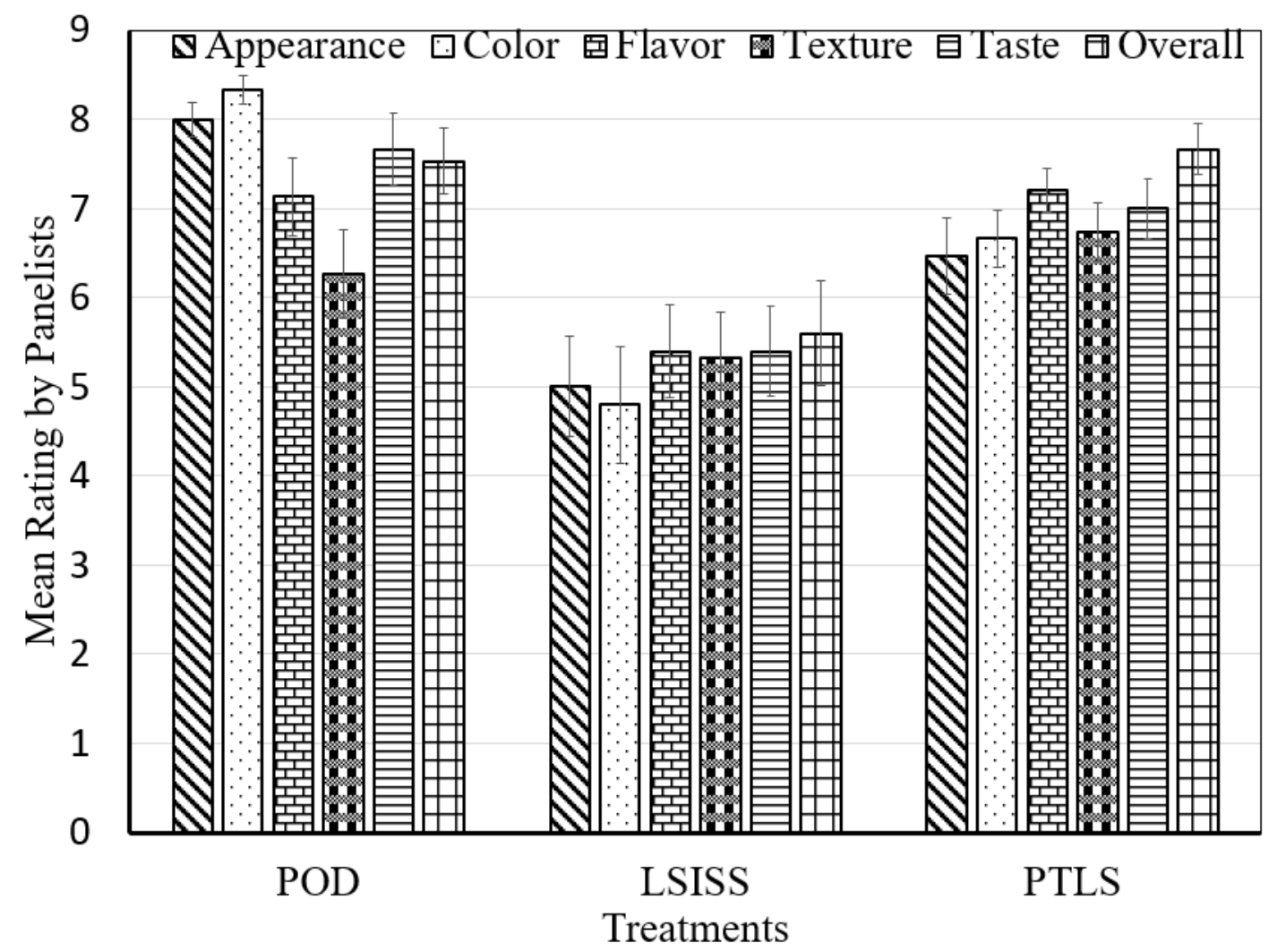

Figure 10. Sensory Characteristics (Appearance, Color, Flavor, Texture, Taste, and Overall Acceptance) Rating by Panelists (mean, standard error) for Dried Apples Produce Through Three Treatments (POD, LSISS, and PTLS)

Gender and age did not significantly affect the preference toward any treatment (POD, PTLS, LSISS) (Figure 11 and 12). The interaction plot for overall acceptance (OA) based on age group for the three treatments is shown in Figure 11. 

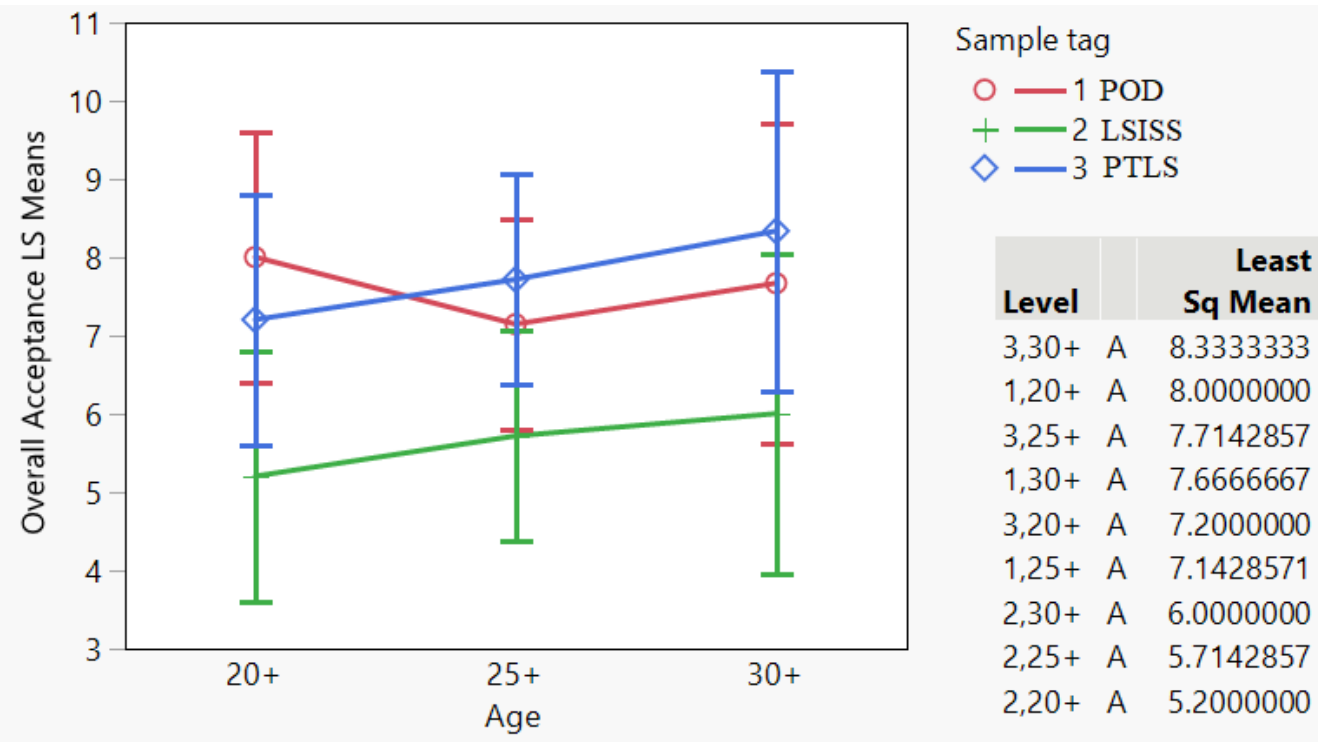

Figure 11. Interaction plot for Overall Acceptance for the Treatments Based on Age

It can be noticed that age did not play any role in choosing one treatment over the other. Panelists of age-group 20-24, 25-29 and 30+ all preferred POD and PTLS over LSISS treatment.

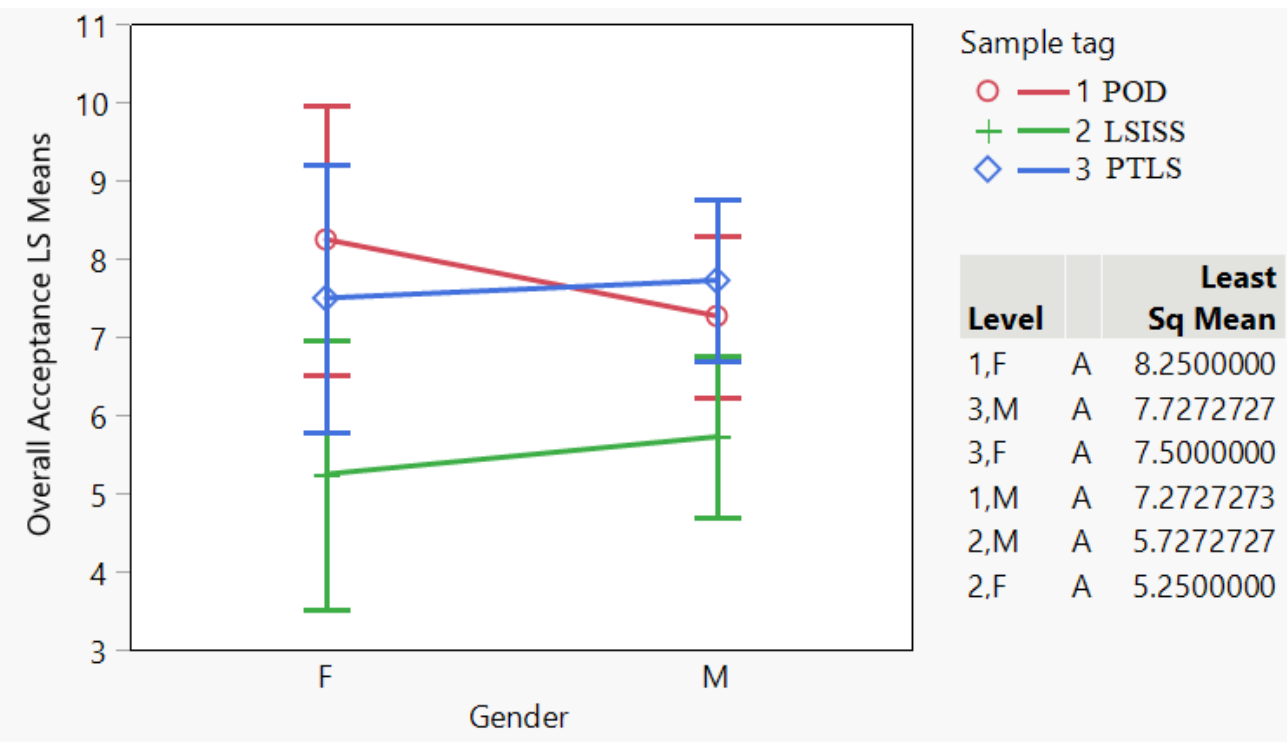

Figure 12. Interaction plot for Overall Acceptance for the Treatments Based on Gender. 
Similarly, based on gender, the interaction plot shows that gender did not play any role in choosing one treatment over the other. Males as well as females preferred POD and PTLS over LSISS treatment. All the other attributes (color, texture, flavor, appearance, taste) all showed similar results as overall acceptance, age or gender did not influence the ratings for all three treatments. 


\section{Chapter 4}

\section{Summary and Conclusions}

Use of liquid smoke (PTLS or LSISS) enhances the solute (sugar) influx inside the fruit. Hence, a higher value of solid gained (SG) is observed when liquid smoke is used with the OD. Use of Liquid Smoke also significantly increases the yield. Dried product yield was calculated to be 23.48 $\%$ for apples with PTLS treatment, which was the highest among all treatments followed by LSISS treatment (22.53\%). However, yield for PTLS and LSISS was not significantly different ( $p>0.05)$ Whereas yield for PTLS and LSISS was significantly more than POD ( $p<0.05)$. Results showed that the moisture content of the apple cubes decreased after the OD from 85.5\% (MC of fresh apples) to 71.64, 68.85 and $69.76 \%$ for POD, LSISS and PTLS, respectively. The highest moisture loss was observed for the LSISS treatment followed by PTLS treatment. Moisture loss for LSISS was significantly higher than POD $(\mathrm{p}<0.05)$ but was not significantly different than PTLS (p>0.05). The highest increase in the SSC of apples after the OD was observed for the PTLS treatment followed by LSISS treatment, which suggested that the more sugar was transferred from solution to the fruit when liquid smoke was used than POD however, increase in SSC for POD and LSISS was not significant. PTLS was significantly higher than POD and LSISS. Likewise, the SSC of the apple cubes with PTLS treatment increased from 12.6 to $31.40{ }^{\circ}$ Brix, the highest among all three treatments. This represented an increase of $149.2 \%$. The highest SG was found for PTLS treatment $(8.38 \%)$ followed by LSISS treatment $(7.37 \%)$. SG was significantly higher for treatments with PTLS and LSISS than the POD $(\mathrm{p}<0.05)$. WL for all three treatment was significantly different. Addition of LS showed higher values for DM compared to pure OD (without LS). Dry matter after OD was the highest for PTLS but was not significant compared to 
LSISS. The dry matter after OD was significantly higher for treatments with PTLS and LSISS than the POD $(\mathrm{p}<0.05)$.

Color and water activity for all three treatments was recorded after 7, 14, 28 days. The color remained the same for all three treatments over 28 days, liquid smoke did not have any effect on retaining better color for longer time; however, the samples treated with liquid smoke had significant lower $L^{*}$ values compares to apples that did not have any liquid smoke in them. Water activity was significantly lower for PTLS and LSISS compared to POD.

For consumer acceptance, the values for flavor, texture, taste and overall acceptance were significantly higher for PTLS and POD than the LSISS treatment $(\mathrm{p}<0.05)$. For appearance and color, all three treatment are significantly different. However, POD got the highest values for appearance and color. We also observe that even though people don't like the color and appearance of PTLS, they still gave higher ratings for taste, texture, flavor and overall acceptance for PTLS treatment. Gender and age did not have any significant impact on preference for the treatments. Consumers regardless of age and gender seems to like apples treated with PTLS as much as they like apples treated with POD. Treatment LSISS was least liked by the consumers and most of them stated, "the flavor is too strong for their liking". The conclusion is if we were to introduce this novel dried smoky apple snack to the market, apples treated with PTLS treatment would be the best choice.

For future research, the effects of liquid smoke on apples without any osmotic dehydration should be studied to better understand how liquid smoke affects the cell structure of apple tissue. Other common apple varieties such as Gala and Granny Smith can also be used in research. Different concentration and time (for pre-treatment) of refined liquid smoke treatment needs to be studied. 
Finally, consumer sensory testing with a population size of 100 is suggested to better understand the marketability and acceptance of the product over a wide population. 


\section{References}

Ahmed, N., Singh, J., Chauhan, H., Anjum, P. G. A., \& Kour, H. (2013). Different Drying Methods: Their Applications and Recent Advances. International Journal of Food Nutrition and Safety, 4(1), 34-42.

Akharume, F., Singh, K., Jaczynski, J., \& Sivanandan, L. (2018). Microbial shelf stability assessment of osmotically dehydrated smoky apples. LWT - Food Science and Technology, 90(December 2017), 61-69. https://doi.org/10.1016/j.lwt.2017.12.012

Akharume, F., Singh, K., \& Sivanandan, L. (2019). Effects of liquid smoke infusion on osmotic dehydration kinetics and microstructural characteristics of apple cubes. Journal of Food Engineering, 246(October 2018), 51-57. https://doi.org/10.1016/j.jfoodeng.2018.10.030

Apple Varieties - USApple. (n.d.). Retrieved June 30, 2020, from https://usapple.org/applevarieties

Ayvaz, Z., \& Atar, H. H. (2016). The Use of Liquid Smoke Condensate in Foods and Its Effect on Health.

Bastin, S., \& Henken, K. (2011). Water Amounts in Fruits and Vegetables. Health Matters Program, 2011.

Berk, Z. (2018). Dehydration. In Food Process Engineering and Technology. Elsevier. https://doi.org/10.1016/B978-0-12-812018-7.00022-1

Bondonno, N. P., Bondonno, C. P., Ward, N. C., Hodgson, J. M., \& Croft, K. D. (2017). The cardiovascular health benefits of apples: Whole fruit vs. isolated compounds. Trends in Food Science \& Technology, 69. https://doi.org/10.1016/j.tifs.2017.04.012 
Brennan, J. G., Grandison, A. S., \& Lewis, M. J. (2006). Separations in Food Processing. In Food Processing Handbook. https://doi.org/10.1002/3527607579.ch14

Cruz, A. C., Guiné, R. P. F., \& Gonçalves, J. C. (2015). Drying Kinetics and Product Quality for Convective Drying of Apples (cvs. Golden Delicious and Granny Smith). International Journal of Fruit Science, 15(1), 54-78. https://doi.org/10.1080/15538362.2014.931166

Dikbasan, T. (2007). Determination of Effective PARAMETER FOR DRYING OF APPLES.

Eren, I., \& Kaymak-Ertekin, F. (2007). Optimization of osmotic dehydration of potato using response surface methodology. Journal of Food Engineering, 79(1), 344-352. https://doi.org/10.1016/j.jfoodeng.2006.01.069

ESTRADA-MUÑOZ, R.; Boyle, E.; Marsden, J., Liquid smoke effects on Escherichia coli O157: H7, and its antioxidant properties in beef products. Journal of Food Science 1998, 63 (1), 150153.

Fruit Production - Statistics \& Facts | Statista. (n.d.). Retrieved June 30, 2020, from https://www.statista.com/topics/1621/fruit-production/

Gomaa, E. A.; Gray, J. I.; Rabie, S.; Lopez-Bote, C.; Booren, A. M., Polycyclic aromatic hydrocarbons in smoked food products and commerical liquid smoke flavourings. Food Additives \& Contaminants 1993, $10(5), 503-521$.

Hattula, T.; Elfving, K.; Mroueh, U.-M.; Luoma, T., Use of liquid smoke flavouring as an alternative to traditional flue gas smoking of rainbow trout fillets (Oncorhynchus mykiss). $L W T$ Food Science and Technology 2001, 34 (8), 521-525. 
Karunasena, H. C. P., Hesami, P., Senadeera, W., Gu, Y. T., Brown, R. J., \& Oloyede, A. (2014). Scanning Electron Microscopic Study of Microstructure of Gala Apples During Hot Air Drying. Drying Technology, 32(4). https://doi.org/10.1080/07373937.2013.837479

Kaymak-Ertekin, F., \& Sultano, M. (n.d.). Modelling of mass transfer during osmotic dehydration of apples. www.elsevier.com/locate/jfoodeng

Khorshidi, J. (2019). Storage temperature effects on the postharvest quality of apple (Malus Storage Temperature Effects on the Postharvest Quality of Apple (Malus domestica Borkh . cv . Red Delicious). July.

Kowalska, Hanna. (2009). Effect of solution concentration, temperature, and process time on osmotic dehydration of apples. Zywnosc. Nauka. Technologia. Jakosc/Food. Science Technology. Quality. 16. 73-85

Koyuncu, T., Tosun, I., \& Pinar, Y. (2007). Drying characteristics and heat energy requirement of cornelian cherry fruits (Cornus mas L.). Journal of Food Engineering, 78(2), 735-739. https://doi.org/10.1016/j.jfoodeng.2005.09.035

Lewicki, P. P., \& Jakubczyk, E. (2004). Effect of hot air temperature on mechanical properties of dried apples. Journal of Food Engineering, 64(3), 307-314. https://doi.org/10.1016/j.jfoodeng.2003.10.014

Lingbeck, J. M.; Cordero, P.; O'Bryan, C. A.; Johnson, M. G.; Ricke, S. C.; Crandall, P. G., Functionality of liquid smoke as an all-natural antimicrobial in food preservation. Meat science 2014, 97 (2), 197-206. 
Maltini, E., Torreggiani, D., Venir, E., \& Bertolo, G. (2003). Water activity and the preservation of plant foods. Food Chemistry, 82(1). https://doi.org/10.1016/S0308-8146(02)00581-2

Martinez, O.; Salmeron, J.; Guillen, M.; Casas, C., Texture profile analysis of meat products treated with commercial liquid smoke flavourings. Food control 2004, 15 (6), 457-461.

Mayor, L., \& Sereno, A. M. (2004). Modelling shrinkage during convective drying of food materials: A review. Journal of Food Engineering, 61(3), 373-386. https://doi.org/10.1016/S0260-8774(03)00144-4

Montazeri, N., Oliveira, A. C. M., Himelbloom, B. H., Leigh, M. B., \& Crapo, C. A. (2013). Chemical characterization of commercial liquid smoke products. Food Science \& Nutrition, 1(1), 102-115. https://doi.org/10.1002/fsn3.9

P, A. (2019). 'Studies on Osmotic Dehydration of Guava (Psidium guajava L.)'. M. Sc. University of Agricultural Sciences GKVK. Bangalore.

Poste L. M., Mackie D A, Butler G \& Larmond E. (1991). Laboratory Methods for Sensory Analysis of Food. Research Branch, Agriculture Canada.

Prosapio, V., \& Norton, I. (2017). Influence of osmotic dehydration pre-treatment on oven drying and freeze drying performance. LWT - Food Science and Technology, 80, 401-408. https://doi.org/10.1016/j.lwt.2017.03.012

Rahmat, B., \& Zhilalul Haq Albaki, A. (2021). 10.11648.j.ijmb.20210602.14. Article in International Journal of Microbiology and Biotechnology, 6(2), 53-58. https://doi.org/10.11648/j.ijmb.20210602.14 
Ramaswamy, H. S., \& Tung -, M. A. (n.d.). Thermophysical Properties of Apples in Relation to Freezing.

Romano, G., Nagle, M., Argyropoulos, D., \& Müller, J. (2011). Laser light backscattering to monitor moisture content, soluble solid content and hardness of apple tissue during drying. Journal of Food Engineering, 104(4), 657-662. https://doi.org/10.1016/j.jfoodeng.2011.01.026

Rupasinghe, H. P. V., Thilakarathna, S., \& Nair, S. (n.d.). Polyphenols: chemistry, dietary sources and health benefits.

Sabarez, H. T. (2016). Airborne Ultrasound for Convective Drying Intensification. In Innovative Food Processing Technologies: Extraction, Separation, Component Modification and Process Intensification (pp. 361-386). Elsevier Inc. https://doi.org/10.1016/B978-0-08-100294-0.00014-6

Scott, V. N., \& Bernard, D. T. (1983). Influence of Temperature on the Measurement of Water Activity of Food and Salt Systems. Journal of Food Science, 48(2). https://doi.org/10.1111/j.13652621.1983.tb10788.x

Sharif, M. K., Butt, M. S., Sharif, H. R., \& Nasir, M. (2017). Sensory Evaluation and Consumer Acceptability. Handbook of Food Science and Technology, October, 362-386. https://www.researchgate.net/publication/320466080

Siebert, T., Becker, A., Bunzel, M., Zuber, M., Hamann, E., Baumbach, T., Karbstein, H. P., \& Gaukel, V. (2020). Evaluation of the usefulness of serial combination processes for drying of apples. Drying Technology, 38(10). https://doi.org/10.1080/07373937.2019.1637888

Šimko, P., Factors affecting elimination of polycyclic aromatic hydrocarbons from smoked meat foods and liquid smoke flavorings. Molecular nutrition \& food research 2005, 49 (7), 637-647. 
Slavin, J. U. of M., \& Lloyd Beate, P. N. G. R. (2012). Health Benefits of Cassava-Karrapendalam. Www.Yadtek.Com , Health , Diet \& Nutrition, 3(4), 506-516. https://doi.org/10.3945/an.112.002154.506

Southon, S. (2000). Increased fruit and vegetable consumption within the EU: Potential health benefits. Food Research International, 33(3-4), 211-217. https://doi.org/10.1016/S09639969(00)00036-3

Swastawati, F., Agustini, T. W., Darmanto, Y., \& Dewi, E. N. (2007). Liquid Smoke Performance of Lamtoro Wood and Corn Cob. Journal of Coastal Development, 10(3), 1410-5217.

Torreggiani, D. (1993). Osmotic dehydration in fruit and vegetable processing. Food Research International, 26(1), 59-68. https://doi.org/10.1016/0963-9969(93)90106-S

Torreggiani, D., \& Bertolo, G. (2004). Present and Future in Process Control and Optimization of Osmotic Dehydration From Unit Operation to Innovative Combined Process: AN OVERVIEW.

U.S. Apple Association. (2018). 2018 Production \& Utilization Analysis. https://wstfa.org/wstfaassets/uploads/USApple2018ProductionAnalysis.pdf

USDA. (2011, July). Apple Production in the United Stated. https://www.ers.usda.gov/dataproducts/chart-gallery/gallery/chart-detail/?chartId=75112

USDA. (2019, April). Fruits and Fruit Juices. FDC ID: 171688. https://fdc.nal.usda.gov/fdcapp.html\#/food-details/171688/nutrients

Wang, W.; Li, C.; Zhang, H.; Ni, Y., Using liquid smoke to improve mechanical and water resistance properties of gelatin films. Journal of Food Science 2016, 81 (5), E1151-E1157. 
Witrowa-Rajchert, D., \& Rząca, M. (2009). Effect of Drying Method on the Microstructure and Physical Properties of Dried Apples. Drying Technology, 27(7-8). https://doi.org/10.1080/07373930903017376

Zotarelli, M. F., Porciuncula, B. D. A., \& Laurindo, J. B. (2012). A convective multi-flash drying process for producing dehydrated crispy fruits. Journal of Food Engineering, 108(4), 523-531. https://doi.org/10.1016/j.jfoodeng.2011.09.014 